УДК 373.14:004.9

Науменко Ольга Михайлівна

молодший науковий співробітник відділу лабораторних комплексів засобів навчання Інститут інформаційних технологій і засобів навчання НАПН України, м. Київ, Україна o.naumenko@iitta.gov.ua

\title{
ІНТЕРНЕТ-РЕСУРСИ І ПІДВИЩЕННЯ ЯКОСТІ ШКІЛЬНОЇ ХIMІЧНОÏ ОСВІТИ
}

\begin{abstract}
Анотація. Розглядається питання застосування Інтернет-ресурсів 3 метою підвищення якості шкільної хімічної освіти. Якість освіти трактується як процес і як результат. Із позицій процесу, якість освіти - це стан системи освіти в цілому й умови освітньої діяльності у кожному навчальному закладі зокрема; як результат - вказує на відповідність рівня підготовки учнів вимогам Державного стандарту освіти і чинних освітніх програм, здатність задовольняти освітні запити особистості, відповідати потребам суспільства i держави. Зазначається, що розвиток системи шкільної освіти потребує постійного оновлення технологій, прискореного впровадження інновацій, швидкої адаптації до економічних і технологічних змін у світі.
\end{abstract}

Ключові слова: Інтернет; інформатизація освіти; якість освіти; вивчення хімії.

\section{1. ВСТУП}

Побудова інформаційного суспільства як суспільства знань передбачає створення індустрії розробки, апробації і запровадження у практику роботи шкіл засобів мультимедійних технологій, зокрема Інтернет орієнтованих педагогічних технологій, що грунтуються на широкому використанні інтернет-ресурсів 3 метою досягнення високої якості освіти. Новизна вказаних технологій обумовлює потребу у формуванні цілісної наукової методології застосування засобів, прийомів і методів навчання на базі певної науково-методичної концепції, що визначає загальні дидактичні принципи й ідеї використання інформаційно-комунікаційних технологій у школі, взаємодію i взаємопроникнення з іншими педагогічними технологіями.

Постановка проблеми. Як зазначається у Концепції Державної цільової соціальної програми підвищення якості шкільної природничо-математичної освіти на період до 2015 року, що затверджена Розпорядженням Кабінету Міністрів України від 27 серпня 2010 р. № 1720-p: "Поліпшення якості шкільної освіти, зокрема природничоматематичної, $\epsilon$ необхідною умовою формування інноваційного суспільства та підвищення конкурентоспроможності економіки. Розвиток системи шкільної освіти потребує постійного оновлення технологій, прискореного впровадження інноваційних технологій, іiї швидкої адаптації до політичних, економічних та технологічних змін у світі" [2].

Мало дослідженою залишається проблема створення і використання Інтернетресурсів як засобу підвищення якості освіти в цілому, і якості шкільної хімічної освіти зокрема. В усіх розвинених і в багатьох країнах, що розвиваються, здійснюються широкомасштабні програми інформатизації освіти. Усе більш повно проявляється у світовій практиці тенденція широкого використання дистанційних технологій навчання як найважливішого компонента системи відкритої освіти. На цьому фоні стан інформатизації української освіти можна оцінити як незадовільний. Найбільш складною i важливою ланкою тут $\epsilon$ загальноосвітня школа. Через відсутність національної політики в розробці навчальних ресурсів мережі Інтернет освітні сайти, 
що з'являються, часто мають невисоку якість і тому, як правило, мало застосовуються у педагогічній практиці, що, у свою чергу, не справляє значного впливу на якість освіти.

Аналіз останніх досліджень і публікацій. Науково-технічна революція, що нестримно розвивається, стала основою глобального процесу інформатизації усіх сфер життя суспільства. Рівень і темпи інформаційно-технологічного розвитку багато в чому визначають стан економіки, якість життя людей, національну безпеку, роль країни у світовій спільноті. В умовах світу, що динамічно змінюється, глобальної взаємозалежності і конкуренції, необхідності широкого використання, постійного розвитку й ускладнення технологій фундаментальне значення має інформатизація сфери освіти. Зміст і якість освіти, їі доступність, відповідність потребам конкретної особи визначають стан інтелектуального потенціалу сучасного суспільства. Інтенсивний розвиток сфери освіти на основі використання інформаційних i телекомунікаційних технологій стає найважливішим національним пріоритетом [7].

Метою статті $\epsilon$ розгляд питання про можливості використання Інтернет-ресурсів загальнонаукового і навчального призначення для підвищення якості шкільної хімічної освіти.

\section{2. РЕЗУЛЬТАТИ ДОСЛІДЖЕННЯ}

Якість освіти науковцями i педагогами-практиками розглядається у різних трактуваннях цього поняття: як процес і як результат. Із позицій процесу, якість освіти - це стан системи освіти в цілому та умови освітньої діяльності у кожному навчальному закладі зокрема; як результат - вказує на відповідність рівня підготовки учнів вимогам Державного стандарту освіти і чинних освітніх програм, здатність задовольняти освітні запити особистості, відповідати потребам суспільства і держави.

Питанням якості освіти присвячені наукові роботи Ю. Бабанського, В. Беспалька, I. Зязюна, В. Кременя, В. Лугового, В. Маслова, В. Панасюка, М.Поташника, О. Савченко, М. Скаткіна, Т. Шамова та інших [6]. Важливі аспекти моніторингу якості освіти розглянуті у роботах В. Бикова, Ю. Жука, О. Лященка, О. Локшиної, Т. Лукіної та інших $[1,3,4]$.

Серед чинників, що визначають якість освіти, на першому місці - iї зміст. У вже згадуваній Концепції Державної цільової соціальної програми підвищення якості шкільної природничо-математичної освіти на період до 2015 року, серед причин низької якості природничо-математичної освіти відзначається недосконалість змісту шкільної освіти внаслідок невизначеності пріоритетних напрямів навчання, перевантаження природничо-математичних предметів фактологічним i другорядним матеріалом; учителі традиційно орієнтовані на запам'ятовування учнями певних абстрактних алгоритмів дій, а не на організацію пошукової діяльності, розвиток самостійності мислення, формування відповідних компетентностей.

Результати участі учнів 4-x і 8-x класів у міжнародних порівняльних дослідженнях якості шкільної природничо-математичної освіти підтверджують нездатність українських школярів використовувати набуті знання й уміння у реальних ситуаціях повсякденного життя. Такі недоліки зберігаються до закінчення школи, про що свідчать результати аналізу виконання випускниками завдань зовнішнього незалежного оцінювання з природничо-математичних предметів [2].

Другий важливий чинник якості освіти - це управління системою освіти, як на мікро-, так і на макрорівнях. Без ефективного управління системою практично неможливо досягти раціонального використання наявного ресурсного забезпечення, особливо в умовах обмеженого фінансування. Третій чинник якості освіти - ресурсне забезпечення навчально-виховного процесу. Незадовільний стан матеріально- 
технічного забезпечення загальноосвітніх навчальних закладів характеризується такими показниками: на початок 2009/2010 н. р. рівень забезпеченості шкіл засобами навчання в цілому по Україні становив 29,3 відсотки від загальної потреби, забезпеченості лабораторним обладнанням кабінетів фізики, біології та хімії - 10-15 відсотків, що негативно впливало на проведення лабораторно-практичних робіт 3 природничих предметів, на якість освіти, дотримання вимог відповідного державного освітнього стандарту.

Серед ресурсного забезпечення якості освіти слід відзначити зміст начальних $\mathrm{i}$ методичних посібників, рівень фахової підготовки педагогічних кадрів, оснащення навчальних закладів сучасними засобами інформаційно-комунікаційних технологій. Якщо мова йде про сучасну освіту, то серед показників якості освіти "однією із найголовніших якостей особистості в сучасних умовах, що потрібно формувати i розвивати зі шкільної лави, - це уміння працювати із потоками інформації". Це висловлювання належить засновнику і керівнику корпорації Microsoft Біллу Гейтсу, який включав до цього поняття вміння володіти комп'ютером i користуватися ресурсами Інтернету у своїй навчальній та професійній діяльності [8]. Іншими словами, мова йде про інформатичну компетентність людини. Сприяти формуванню такої компетентності має і використання Інтернет-ресурсів у процесі вивчення хімії.

Масове використання інформаційно-комунікаційних технологій у шкільній освіті за останні роки призвело до суттєвого зростання навчальних інформаційних ресурсів мережі Інтернет. Однак слід зазначити, що українські Інтернет-ресурси, які можна використовувати для вивчення шкільного курсу хімії, суттєво поступаються за обсягом і якістю аналогічним російським. Для прикладу: за одним і тим же запитом одна й та ж пошукова система серед російськомовних ресурсів знаходить понад 4 млн. сторінок, а українських - лише 1 тис. сторінок; та й серед них більшість - це прихована реклама, сайти науково-дослідних установ, підприємств хімічної промисловості, публікації ЗМІ тощо. Це пояснюють переважно тим, що в Російській Федерації діє програма запровадження Інтернет-ресурсів в освіту, відповідно до якої центри інформаційних технологій при вищих навчальних закладах і дослідницьких організаціях, видавництва навчальної і науково-популярної літератури створили спеціалізовані навчальні сервери і сайти в Інтернеті. Досить масово створюють власні сайти навчальні заклади різних типів, окремі вчителі й науковці. Сприяє поширенню Інтернет-ресурсів і той факт, що переважна більшість матеріалів навчального характеру знаходиться у вільному доступі.

Ресурси Інтернету з хімії за змістом можна розділити на такі групи:

- проспекти i демонстраційні версії електронних засобів навчального призначення для підтримки шкільного курсу хімії, безкоштовні версії комп'ютерних програм;

- бази даних, електронні версії науково-популярних і методичних журналів, матеріалів конференцій, окремих статей тощо;

- програми-екзаменатори, програми для тестування та інші електронні засоби контролю за рівнем навчальних досягнень учнів.

Окремі вищі навчальні заклади через Інтернет проводять підготовчі курси для вступу, дистанційні вікторини й олімпіади серед випускників шкіл.

Навчальні Інтернет-ресурси 3 хімії можуть бути корисними як під час вивчення нового матеріалу, так і для проведення лабораторних чи практичних робіт. Завдяки таким ресурсам стає можливим знайомство учнів 3 хімічними речовинами $\mathrm{i}$ демонстрація дослідів, які з різних причин недоступні для школи. Серед популярних Інтернет-ресурсів - електронні підручники, навчальні та методичні посібники з хімії, віртуальні хімічні лабораторії, хімічні каталоги, бази даних, таблиці, атласи, колекції матеріалів, електронні видання, що популяризують застосування хімії, тощо. Усе це 
дозволяє підвищити наочність і доступність змісту шкільного курсу хімії, а тим самим суттєво вливає на якість шкільної хімічної освіти.

Учитель хімії може використовувати інформаційні ресурси мережі Інтернет за такими напрямками:

1) самоосвіта, вивчення досвіду колег, підготовка до методичних семінарів, розробка атестаційних матеріалів тощо;

2) підготовка до уроків, створення дидактичних матеріалів; використання у ході уроку довідкових матеріалів, схем, таблиць, малюнків, відеороликів; демонстрація хімічних дослідів і технологічних процесів, які неможливо відтворити в умовах шкільного кабінету хімії;

3) позакласна робота 3 учнями для поглибленого оволодіння хімічними знаннями; участь у дистанційних предметних олімпіадах;

4) проведення тестування та інших форм тематичного контролю за рівнем навчальних досягнень учнів.

Технічно роботу з Інтернет-ресусами у ході уроку можна організувати у двох варіантах.

Перший: учні можуть працювати в режимі on-line, тобто 3 безпосереднім доступом до Інтернету. Цей варіант рекомендується у тих випадках, коли у навчальному закладі є достатня кількість комп'ютерів 3 досить швидким доступом до Інтернету і завантаження навчальних матеріалів не займає багато часу. Однак і у цьому випадку вчитель має попередньо перевірити доступність необхідних Інтернет-ресурсів, оскільки сервери і сайти можуть бути з різних технічних причин тимчасово недоступні.

Другий варіант - більш надійний - 3 опосередкованим доступом до Інтернетресурсів, коли вчитель під час підготовки до уроку копіює необхідні веб-сторінки у окрему папку на шкільному сервері.

У будь-якому варіанті доступ до Інтернет-ресурсів навчального призначення для вчителя хімії підвищує як рівень професійної компетентності самого вчителя, так і рівень проведення занять, а отже - і якість знань учнів. Наразі інтерес учнів до роботи 3 комп'ютером і ресурсами Інтернету суттєво вливає на мотивацію до навчання і створює передумови технологічної освіти XXI століття.

Для вчителів-практиків корисною буде інформація про окремі Інтернет-ресурси, які можна використовувати в навчальному процесі.

- http://www.teacher.in.ua/ - український освітній портал, що містить методичні розробки уроків, матеріали для підготовки до уроків і самоосвіти вчителів, реферати, підготовчі курси до ЗНО, довідники, журнали, підручники, інші навчальні матеріали.

- http://metodportal.net/node/588 - український методичний портал, що містить, зокрема, різноманітні Інтернет-ресурси для вчителів хімії.

- http://osvita.ual - український освітній портал, де розміщено велику кількість науково-методичних матеріалів з вільним доступом.

- http://school-collection.edu.ru/ - колекція цифрових освітніх ресурсів.

- http://fcior.edu.ru/ - Федеральний центр інформаційно-освітніх ресурсів.

- http://www.alleng.ru/edu/chem2.htm - освітні ресурси Інтернету з хімії, містить широкий перелік посилань.

- http://chemistry.ru/course/content/ - огляд Інтернет-ресурсів 3 хімії, що систематизований за розділами "Інститути, університети, наукові товариства", "Тематичні сайти", "Інформаційні сервери та електронні журнали", "Хімічні програми", "Електронні конференції", "Приватні хімічні сторінки"; зокрема, тут розміщено досить повний перелік електронних засобів навчального призначення, що доступні в глобальній інформаційній мережі. 
- http://www.openclass.ru/ - мережева спільнота "Відкритий клас", що містить різноманітні навчальні і методичні матеріали для вчителів.

- http://www.maratakm.narod.ru/ - віртуальна хімічна школа.

- http://www.edu.ru/catalog/ - каталог освітніх ресурсів мережі Інтернет.

- http://www.college.ru/chemistry/ - сайт "Відкрита хімія" сервера "Відкритий коледж", де $є$ значна кількість матеріалів для учнів і вчителів; підтримується товариством "Фізикон" Московського фізико-технічного інституту; на ньому організовані системи дистанційного навчання, зокрема, електронні підручники, тести, інтерактивні хімічні моделі, інтерактивна таблиця періодичних елементів, перелік ресурсів "Хімія в Інтернеті" тощо.

- http://www.chem.msu.su:8081/rus/elbibch - електронна бібліотека хімічного факультету Московського державного університету імені М. В. Ломоносова; розміщені електронні версії навчальних і методичних посібників, монографій, хімічних журналів, збірники олімпіадних задач 3 хімії, навчальні бази даних, відомості про видатних хіміків тощо.

- http://www.chem.msu.ru - інформаційна мережа CHEMNET, що створена Інформаційним центром хімічного факультету МДУ; розміщені довідники "Хімічний факультет МДУ", "Університети Росії", "Хімічні інститути і факультети", "Асоціація хімічної освіти", "Бази даних та інші джерела інформації з хімії", "Конференції та семінари", "Конкурси та олімпіади", «Журнал Российского химического общества им. Д. И. Менделеева»; наведені посилання на власні бази даних 3 хімії і бази даних на серверах інших університетів.

- http://http://him.1 september.ru - сайт газети «Химия» видавничого дому «Первое сентября»; доступні електронні версії архівних номерів, починаючи з 1997 року, найбільш цікаві проблемні статті, новини хімічної науки і технологій, методики навчання хімії тощо.

- http://markovsky.virtualave.net/chemonline/ - «Химия on-line» («Химия в Сети»); містить велику добірку посилань на ресурси й авторські розробки в галузі програмних моделей хімічних процесів і хімічних розрахунків; різноманітні мережеві форуми і телеконференції; тут же розміщені посилання на каталог програм 3 хімії chemicsoft.chat.ru.

- http://www.informika.ru/text/database/chemy/ - наведені текстові і графічні матеріали посібника "Хімія для всіх" і безкоштовні програми навчального характеру, довідники із загальної, аналітичної та органічної хімії, добірки статей з хімії, довідкові дані про хімічні елементи.

- http://www.examen.ru - сервер «Екзамен», на якому з хімії є розділи "Загальна хімія" (20 документів), "Органічна хімія" (11), "Неорганічна хімія" (17), "Реферати" (40), "Видатні хіміки" (22), "Історія хімії" (5); наведені також посилання на корисні навчальні ресурси з хімії.

- http://rostest.runnet.ru - сервер "Ростест", який підтримується МДУ; містить програми тестування із семи предметів, у т. ч. 3 хімії; корисно використовувати як тренажер для підготовки до ЗНО в режимі самостійної роботи учнів.

Глобальна інформаційна мережа стає складовою частиною сучасної освіти, оскільки має величезний потенціал послуг, серед яких: електронна пошта, пошукові системи, електронні конференції і форуми. Користуючись Інтернет-ресурсами, учні отримують навички цілеспрямованого пошуку потрібної інформації і її систематизації за певними ознаками, навчаються сприймати інформацію в цілому, а не фрагментарно, виокремлювати суттєве в інформаційних потоках.

Використання готових електронних засобів навчального призначення дозволяє інтенсифікувати спільну діяльність вчителя й учня, що підвищує якість навчання. 
Засобами мультимедія навчальний матеріал розгортається як система структурованої інформації, у поданні якої задіяні різні канали сприйняття, що, у свою чергу, сприяє іiі ефективному засвоєнню.

Можливості використання Інтернет-ресурсів на уроках хімії можна визначити так:

- створення проблемної ситуації на уроці, ознайомлення з різними поглядами на певну проблему;

- пошук необхідної інформації для виконання проектних, дослідницьких робіт, підготовки доповідей і рефератів;

- організація телекомунікаційних конференцій, семінарів. вікторин, олімпіад;

- проведення тестування та інших форм контролю рівня навчальних досягнень учнів;

- дистанційне навчання, самоосвіта; можливість спілкування з віддаленими освітніми центрами;

- підвищення мотивації до навчання через організацію індивідуального підходу до кожного учня.

Інформаційні технології дозволяють будувати відкриту систему освіти, корінним чином змінювати організацію процесу навчання, раціонально організовувати пізнавальну діяльність, формуючи в учнів навички системного мислення. За прогнозними оцінками фахівців, освіта on-line буде поступово витісняти традиційну систему освіти, оскільки використання комп'ютерів і відповідних електронних засобів навчального призначення дозволяє індивідуалізувати навчальний процес на основі принципово нових пізнавальних ресурсів.

\section{3. ВИСНОВКИ ТА ПЕРСПЕКТИВИ ПОДАЛЬШИХ ДОСЛІДЖЕНЬ}

Для використання Інтернет-ресурсів з метою підвищення якості шкільної хімічної освіти можемо виокремити низку важливих завдань, що мають бути розв'язані у процесі розвитку української школи.

1. Аналіз змісту шкільного курсу хімї з точки зору формування комп'ютерно орієнтованого освітнього середовища.

Такий аналіз має на меті встановлення меж необхідної комп'ютерної підтримки навчального предмета, створення електронних посібників навчального призначення, розробки і запровадження комп'ютерно орієнтованих методичних систем навчання.

Ще одне завдання, що має бути розв'язане у ході аналізу змісту освіти, - це гармонійне, педагогічно виважене поєднання традиційних освітніх технологій і засобів ІКТ й Інтернет-ресурсів.

2. Використання засобів інформаційно-комунікаційних технологій у навчальному прочесі, комп'ютерна підтримка вивчення хімії.

Головне завдання - це розробка навчальних посібників, до змісту і структури яких вже закладено необхідну комп’ютерну підтримку з метою уникнення інформаційного перевантаження учнів і поліпшення якості освіти.

Інша складова цього завдання - створення технічного оснащення навчальних закладів, що має забезпечити організацію навчального процесу на засадах широкого використання засобів ІКТ й Інтернет-ресурсів.

3. Підготовка педагогічних прачівників до роботи в умовах комп'ютерно орієнтованого освітнього середовища.

Це питання є найбільш важливим для забезпечення якості сучасної освіти. Нині кожен учитель-предметник має володіти засобами IКТ і методикою їх застосування у навчальному процесі. Тому процес підготовки педагогічних працівників має включати оволодіння необхідними технологічними знаннями 3 комп'ютерних засобів 
навчального призначення, педагогічними засадами використання відповідних методик застосування програмних і технологічних засобів у навчальному процесі [5].

4. Вивчення, аналіз $i$ узагальнення досвіду використання комп'ютерно орієнтованих засобів навчання, розробка на иій основі нових методик застосування засобів ІКТ у навчальній діяльності.

Як уже зазначалося, на сьогоднішній день відсутня система науково-методичного й організаційно-управлінського супроводження використання засобі ІКТ у шкільній навчальній діяльності. Без створення такої системи неможливо оцінити ефективність тих чи інших засобів, доцільність їх використання у навчальному процесі, можливості удосконалення тощо.

5. Створення індустрії інформатизачії освіти, зокрема:

- розробка, апробація і вільне поширення електронних засобів навчального призначення;

- розвиток Інтернету; формування навчальних Інтернет-ресурсів 3 вільним доступом;

- створення мережі технічного і програмного обслуговування навчальних закладів, оновлення техніки і програмного забезпечення.

\title{
СПИСОК ВИКОРИСТАНИХ ДЖЕРЕЛ
}

1. Биков В. Ю. Моніторинг рівня навчальних досягнень 3 використанням Інтернет-технологій : [монографія] / Биков В. Ю., Богачков Ю. М., Жук Ю. О. / за ред. В. Ю. Бикова, Ю. О. Жука. - К. : Педагогічна думка, 2008. - 128 с.

2. Розпорядження Кабінету Міністрів України від 27 серпня 2010 р. № 1720-р "Про схвалення Концепції Державної цільової соціальної програми підвищення якості шкільної природничоматематичної освіти на період до 2015 року" [Електронний ресурс]. - Режим доступу : http://www.kmu.gov.ua/kmu/control/uk/cardnpd.

3. Моніторинг якості освіти: світові досягнення та українські перспективи / за заг. ред. О. І. Локшиною. - К. : "К.І.С.", 2004. - 128 с.

4. Моніторинг якості освіти: становлення та розвиток в Україні (Рекомендації з освітньої політики / за заг. ред. О. І. Локшиною. - К. : "К.І.С.", 2004. - 160 с.

5. Науменко Г. Г., Науменко О. М. Підготовка вчителя в умовах застосування ІКТ / Г. Г. Науменко, О. М. Науменко // Комп’ютер у школі та сім’ї. - 2008. - № 8. - С. 6-10

6. Проблеми якості шкільної освіти: теоретичні і практичні аспекти // Матеріали методологічного семінару АПН України (15 листопада 2006 р., Київ). - К. : СПД Богданова А. М., 2007. - 336 с.

7. Стратегії реформування освіти в Україні: Рекомендації з освітньої політики / за заг. ред. В. П. Андрущенка. - К. : "К.І.С.", 2003. - 164 с.

8. Дженет Лоу. Говорит Билл Гейтс. - М. : АСТ, Транзиткнига, 2004. - 87 с.

Матеріал надійшов до редакиї 14.03.2013 p.

\section{ИНТЕРНЕТ-РЕСУРСЫ И ПОВЫШЕНИЕ КАЧЕСТВА ШКОЛЬНОГО ХИМИЧЕСКОГО ОБРАЗОВАНИЯ}

\author{
Науменко Ольга Михайловна \\ младший научный сотрудник отдела лабораторных комплексов средств обучения \\ Институт информационных технологий и средств обучения НАПН Украины, г. Киев, Украина \\ o.naumenko@iitta.gov.ua
}

Аннотация. Рассматривается вопрос применения Интернет-ресурсов с целью повышения
качества школьного химического образования. Качество образования трактуется как
процесс и как результат. С позиций процесса, качество образования - это состояние
системы образования в целом и условия образовательной деятельности в каждом учебном 
заведении в частности; как результат - указывает на соответствие уровня подготовки учеников требованиям Государственного стандарта образования и действующих образовательных программ, способность удовлетворять образовательные запросы личности, отвечать потребностям общества и государства. Отмечается, что развитие системы школьного образования требует постоянного обновления технологий, ускоренного внедрения инноваций, быстрой адаптации к экономическим и технологическим изменениям в мире.

Ключевые слова: Интернет; информатизация образования; качество образования; изучение химии.

\title{
INTERNET RESOURCES AND IMPROVING THE QUALITY OF SCHOOL CHEMICAL EDUCATION
}

\author{
Olga M. Naumenko \\ junior researcher of the Department of laboratory complexes and learning tools \\ Institute of Information Technologies and Learning Tools of the NAPS of Ukraine, Kyiv, Ukraine \\ o.naumenko@iitta.gov.ua
}

\begin{abstract}
The problem of Internet-resources usage aiming to improve the quality of school chemical education is examined in the article. Quality of education is interpreted as a process and as a result. From positions of process, quality of education is the state of the system of education on the whole and conditions of educational activity in every educational establishment in particular; as a result - specifies compliance with the level of students preparation to the requirements of the State standard of education and operating educational programs, ability to satisfy the educational queries of personality, to meet the needs of society and the state. It is noted, that development of the school system requires constant updating of technologies, speed-up introduction of innovations, and rapid adaptation to the economic and technological changes in the world.
\end{abstract}

Keywords: Internet; informatization of education; quality of education; study of chemistry.

\section{REFERENCES (TRANSLATED AND TRANSLITERATED)}

1. Bykov V. Yu., Bohachkov Yu. M., Zhuk Yu. O. Monitoring of level of educational achievements with the use of Internet-technologies: [monohrafiia] / Za red. V. Yu. Bykova, Yu. O. Zhuka. - K.: Pedahohichna dumka, 2008. - 128 s. (in Ukrainian)

2. Rozporiadzhennia Kabinetu Ministriv Ukrainy vid 27 serpnia 2010 r. № 1720-r "Pro skhvalennia Kontseptsii Derzhavnoi tsiliovoi sotsialnoi prohramy pidvyshchennia yakosti shkilnoi pryrodnycho-matematychnoi osvity na period do 2015 roku" [online] // Available from: http://www.kmu.gov.ua/kmu/control/uk/cardnpd (in Ukrainian)

3. Monitoring of quality of education : world achievements and Ukrainian prospects / Za zah.red. O. I. Lokshynoi. - K. : "K.I.S.", 2004. - 128 s. (in Ukrainian)

4. Monitoring of quality of education: becoming and development in Ukraine. (Recommendations from educational politics) / Pid zah. red. O. I. Lokshynoi. - K.: "K.I.S.", 2004. - 160 s. (in Ukrainian)

5. Naumenko H.H., Naumenko O.M. Preparation of teacher under the conditions of ICT usage // Kompiuter u shkoli ta simi. - 2008. - № 8. - S. 6-10. (in Ukrainian)

6. Problems of quality of school education: theoretical and practical aspects. Materials of methodological seminar of APS of Ukraine. on November, 15, 2006, Kyiv. - K. : SPD Bohdanova A. M., 2007. - 336 s. (in Ukrainian)

7. Strategies of reformation of education in Ukraine: Recommendations from educational politics / Pid zah. red. V. P. Andrushchenka - K. : "K.I.S.", 2003. - 164 s. (in Ukrainian)

8. Janet Lou. Byll Heits talks. - M. : AST, Tranzytknyha, 2004. - 87 s. (in Russian) 